\title{
PERIODONTOLOGIJOS ISTORINE RAIDA. ŠIUOLAIKINIAI PERIODONTOLOGINIAI ZONDAI
}

\author{
Martyna Ambrazaitytė, Miglė Kalinaitė, Eglė Jagelavičienė \\ Lietuvos sveikatos mokslu universiteto Burnos priežiūros ir vaiku odontologijos klinika, \\ Dantu ir burnos ligu klinika
}

Raktažodžiai: periodontologija, istorija, periodontologiniai zondai.

\begin{abstract}
Santrauka
Periodonto ligomis žmonès serga nuo seniausių laikų, joms gydyti taikytos pačios įvairiausios priemonès vaistažolès, burtai, maldos, dantenų masažai, molio tabletès, užkalbẻjimai ir kt. Burnos higienos svarbai daug dèmesio jau buvo skirta senovės Indijoje ir Kinijoje. Šiuolaikinis, mokslo žiniomis grindžiamas gydymas ir sudėtingesnių periodontologinių instrumentų taikymas prasidejo tik XVIII a. Periodonto ištyrimui skirti periodontologiniai zondai gerokai ištobulejo nuo vienapusio rankinio pirmosios kartos instrumento iki sudėtingų kompiuterizuotų prietaisų.
\end{abstract}

\section{Ivadas}

Periodonto ligos žmoniją kamuoja nuo pačių seniausių laikų. Burnos ertmės ir dantų ligų požymių yra rasta priešistorèje gyvenusių žmonių išlikusiuose palaikuose, o seniausi ligų gydymo būdai buvo aprašyti ankstyvųų civilizacijų rašytiniuose šaltiniuose. Daugybę amžių šioms ligoms gydyti žmonès taikè pačias įvairiausias priemones, tokias kaip vaistažolès, burtai, maldos. Tačiau pirmieji veiksmingi gydymo metodai buvo pradèti naudoti tik vẻlesniais laikais, o šiuolaikinis gydymas, taikomas naudojant sudettingesnius ịrankius ir grindžiamas mokslo žiniomis, prasidèjo tik XVIII a. Periodonto ligos iki XIX a. vidurio dažniausiai buvo gydomos šaknų ir dantų šalinimu, taip pat ịvairiais būdais buvo bandoma nuslopinti nemalonius simptomus. Prieš atsirandant periodontologiniams indeksams iki 1950 metų, periodonto sveikata buvo vertinama labai subjektyviai, skirstant ją i gerą, vidutinišką ir blogą. Skirtingų gydytojų gautų duomenų ir studijų rezultatų nebuvo galima lyginti, nes viskas priklausè nuo kiekvieno vertintojo subjektyvaus supratimo, žinių lygio. Todèl periodonto ligų paplitimo dažnis svyravo nuo 8-98\%. Šiuolaikinès priemonès - modernūs periodontologiniai diagnostiniai instrumentai - sukurti labai jautrūs ir efektyvūs periodonto ligų požymių diagnostikoje, taip pat nereikalaujantys subjektyvaus vertinimo.

Darbo tikslas - atlikti mokslinès literatūros analizę ir apžvelgti periodontologijos istorinę raidą bei periodontologinių zondų kartas.

\section{Medžiaga ir metodai}

Literatūros apžvalga atlikta Medline, PubMed Central ir Elsevier duomenų bazèse. Paieškos metu buvo atrinktos anglų kalba parašytos mokslinès publikacijos pagal raktinius žodždius: periodontologija, istorija, periodontologiniai zondai ir išanalizuota periodontologijos vadovèlių bei metodinių leidinių medžiaga. I̦ literatūros apžvalgą įtraukti 28 šaltiniai.

Rezultatai. Surinktos žinios apie įvairiais istoriniais laikotarpiais taikytus periodonto ligų gydymo metodus, priemones, istorinius šaltinius, gydymo metodikų pradininkus ir instrumentų raidos etapus.

Išvados. Per keletą tūkstantmečių žmonès ieškojo būdų periodonto ligoms išgydyti. Apie ịvairiais istorijos laikotarpiais taikytas priemones žinoma iš išlikusių istorinių šaltinių, kurių dèka periodontologijos sritis nuolat tobulejja. Nuolatinis geresnių ir veiksmingesnių priemonių ieškojimas bei tobulinimas didina periodonto ligų gydymo sèkmingumą.

Ankstyvosios civilizacijos. Burnos priežiūrą praktikavo dar senosios Rytų ir Egipto civilizacijos: šumerai, babiloniečiai, asirai. Daugiausia žinių apie jų taikytus gydymo metodus randama molio lentelèse, kurios aptiktos VII a. pr. Kr. sugriautos Asirijos karaliaus Ašurbanipalo bibliotekos liekanose [1-3]. Iki mūsų dienų išlikusiose molinèse lentelèse aprašyti dantenų masažai naudojant ịvairias žolelių mikstūras. Nigelio šventykloje, Mesopotamijoje, rasta dantenų masažui skirtų dekoruotų auksinių dantų krapštukų [2]. Periodonto ligos gydytos molio tabletemis, miros ir opopanakso, pušies sakų mišiniais [1].

Periodonto ligos buvo vienos iš labiausiai paplitusių burnos ligų senovès Egipte, tai pastebi išlikusių balzamuotų kūnų tyrinètojai. Senovès Egipto medicininiuose papirusuose 
(pavyzdžiui, Eberso) aprašyta daugybė dantenų ligų atvejų, nurodyta nemažai tepalų, skirtų dantenų stiprinimui, pateikta receptų, kuriems gaminti naudoti mišiniai iš palmès vaisių, žalio švino, pieno, mètų, medaus, gydymui taip pat taikyta druska bei alus $[1,2]$. Be šių gydomujų priemonių buvo taikomi ir burtai. Buriama pasitelkiant ịvairias magiškas priemones, daiktus, amuletus bei užkalbejjimus. Taip pat svarbu paminèti III a. faraono Djoserio valdymo laikotarpiu Egipte gyvenusi gydytoją Hesy-Ra, praktikavusį dantų ligų gydymą, todèl dabar dažnai laikomą pirmuoju dantistu. Manoma, jog jis pirmasis atpažino periodonto ligas [1,2]. Ankstyvuosiuose hebrajų raštuose apie burnos ligų gydymą rašoma nedaug, tačiau pabrèžiama burnos higiena, kuriai naudoti pipirai, druska, imbieras. Šie produktai taikyti ir malšinti uždegimų sukeltą skausmą [3].

Senoves indai ir kinai burnos, periodonto ligoms bei burnos higienai skyrė ypač daug dèmesio. Jie aprašė dantenų uždegimus, opas, periodonto abscesus [1]. Indijoje (VI a. pr. Kr.) išleistoje knygoje „Susruta Samhita“ yra aprašyti 4 periodonto ligų sukelti pažeidimai: dantenų kraujavimas, pūliavimas, patamsėjimas ir nemalonus kvapas. Šis aprašymas laikomas pirmaja periodonto ligų klasifikacija. Vèlesnèje knygoje „Charaka Samhita“ kalbama apie tinkamą burnos higieną ir dantų valymą specialiai tam pritaikyta lazdele du kartus per dieną, stengiantis nepažeisti dantenų [1]. Taip pat šioje knygoje minimi dviejų rūšių skysčiai, burnos skalavimui - gandoosha ir kavalagra, kurie naudoti skirtingais tikslais. Kavalagra buvo gaminama iš augalinių preparatų, savo konsistencija primine pastą, o gandoosha buvo gaminama iš įvairių aliejų [4].

Legendinio Kinijos valdovo Huang-ti (2500 m. pr. Kr.) knygoje aprašyta daugybė būkliu, lemiančiu burnos sveikatą, taip pat ịtrauktos ir periodonto ligos, detaliai aprašytas dantenų uždegimas, periodonto pūliniai ir opos, kurių gydymui minimi mažiausiai septyni būdai. Taip pat nemažą knygos dali jis paskyrè asmeninei burnos higienai. Tiketina, jog kinai buvo pirmieji pradejję naudoti dantų šepetèlį ir dantų valymui skirtus pagaliukus [1].

Hebrajai taip pat pripažino burnos higienos svarbą. Daugybe dantų ir juos supančių audinių patologijų aprašyta Talmudo raštuose (maždaug 325- 407 m.) [5]. Hebrajų taikytas periodonto ligų gydymas buvo ganètinai primityvus, jų priemonès, tokios kaip pipirai, druska ar imbieras, buvo naudojami skausmo ir blogo burnos kvapo malšinimui. Hebrajų kalba Senajame testamente ir Talmude aprašyta burnos higiena bei dantų netekimo įtaka maitinimosi ypatumams [1].

Antika. Antikos laikotarpiu senovès graikų gyvenime dominavo dievai. Jie tikejjo, kad ligos yra dieviškos bausmès, o pasveikimas - dievų dovana. Iki V a. pr. Kr. buvo bandoma paaiškinti natūralią, o ne dvasinę ligų kilmę. Graikų gydy- tojai pradejjo domètis žmogaus kūnu [2]. Hipokratas, laikomas moderniosios medicinos tèvu, pradejjo atskirti graikų mediciną nuo prietarų ir magijos. Jis taip pat aprašè dantų funkciją, rovimą, periodonto ligų etiologiją, buvo ịsitikinęs, jog dantenų uždegimą gali sukelti ant dantų paviršių besikaupiančios apnašos, o dantenų kraujavimą siejo su blužnies sutrikimais. Jis išleido „Hipokrato rinkinį“, kuriame net 32 skyriuose aprašè dantų ir burnos ertmès patologijas: dantenų skausmą, kraujavimą, blogą burnos kvapą ir galimas burnos ligų priežastis bei išvešejusias dantenas[1,2].

Senovès Romos gyventojų, priklausiusių aukštesniajam visuomenès luomui, burnos ertmès priežiūra buvo panaši ị šiandien gyvenančių žmonių. İdomus tuo laikotarpiu gyvavęs paprotys: ị svečius vakarieniauti atejusiems svečiams padèti ne tik įrankius, bet ir parūpinti auksinius dekoruotus dantų krapštukus, kuriuos svečiai išeidami galedavo pasiimti su savimi [6]. Romėnas Aulas Kornelijus Celsas (Aulus Cornelius Celsus, 25 m.pr. Kr.. -50 m.po Kr.) savo medicininiame rinkinyje aprašè minkštujų burnos audinių ligas ir jų gydymo būdus, tarp jų ir burnos higienos taikymą, pakitusių dantenų gydymą,iš pradžių jas paveikiant ịkaitinta geležimi, o po to patepant medumi $[1,6]$. Daugelyje roménų raštuc yra minimas ir dantų šepetėlio naudojimas [6]. Paulius iš Eginos rašè, kad dantų akmenys turi būti pašalinami su grandukais ar krapštukais, o dantys turi būti kruopščiai išvalomi po paskutiniojo dienos valgymo [1,2].

Senovès Kinijoje buvo skiriamos trys dantų ligų grupès: dantenų ligos, ėduonis ir paslankūs dantys. Dantenų ir dantų ligu gydymui buvo naudojami aliejai, emulsijos, tabletès, milteliai, kartais egzotiški, pagaminti iš žolelių, mineralų, pelių kaulų ir net šlapimo [1]. Skausmo malšinimui buvo taikoma akupunktūra, o dantenų stiprinimui - rekomenduojami masažai. Taip pat Kinijoje buvo gana išsamiai dokumentuojami pacientai: užrašomas jų vardas, liga bei galimas gydymas [3]. Burnos higienos priežiūrai naudoti dantų krapštukai bei ị dantų šepetèlius panašios lazdelès, kurių vienas galas buvo nukramtytas ir naudojamas apnašų šalinimui, o kitas - smailus - skirtas maisto likučių pašalinimui iš tarpdančių [7]. Panašus dantų šepetẻlio aprašymas pateikimas ir to laikotarpio Indijos raštuose.

Viduramžiai. Romėnų imperijos nuosmukis ir griuvimas nubloške Europą į tamsų laikotarpi - Viduramžius, kuriuose iškilo islamas ir arabų mokslas bei medicina. Albukasio (936$1031 \mathrm{~m}$.) laimejjimai odontologijos ir periodontologijos srityse buvo neitikètini [1]. Jo 30 tomų apimančioje medicinos enciklopedijoje, kuri nuo XII a. iki XVII a. naudota Europos universitetuose, iliustruota daugybè instrumentų, tokių kaip pjautuvèliai ir nedideli chirurginiai peiliukai, taikytų dantis supančių audinių gydymui $[1,8]$. Taip pat jis aprašè klibančių dantų tvirtinimą auksine vielute, gana aiškiai suvokè kietujų 
danties apnašų etiologiją ir plačiai išnagrinèjo šių apnašų šalinimo technikas, kurioms taikè savo paties ištobulintus įrankius (1 pav.) [1,3]. Jis suprato, jog kietosios apnašos ant dantų yra pagrindinè periodonto ligų priežastis. Taip pat, atlikdamas periodonto procedūras, Albukasis taikè audinių prideginimo techniką $[1,2]$.

Vienas žymiausių arabų gydytojų Avicena stengèsi kuo rečiau taikyti dantų rovimą, periodonto ligoms gydyti naudojo visas tuo laikotarpiu žinotas medicinos priemones. Taip pat jis paraše traktatą apie daugybę dantenų patologijų, tokių kaip dantenų kraujavimas, opos, recesijos bei jų gydymą [1]. Avicena pabrèžè, jog svarbu rūpintis burnos ir dantų švara ir jai palaikyti siūlè taikyti tokias priemones kaip sraigių kiautų milteliai, elnio ragų pelenai, druska, taip pat naudoti specialiai dantų valymui pritaikytą medinę lazdelę - misvaką (2 pav.) [6,7]. Augalo, iš kurio gaminamos šios lazdelès, sudètyje yra natrio bikarbonatų bei tanino rūgšties - medžiagų, turinčių teigiamą poveikị dantenoms [6].

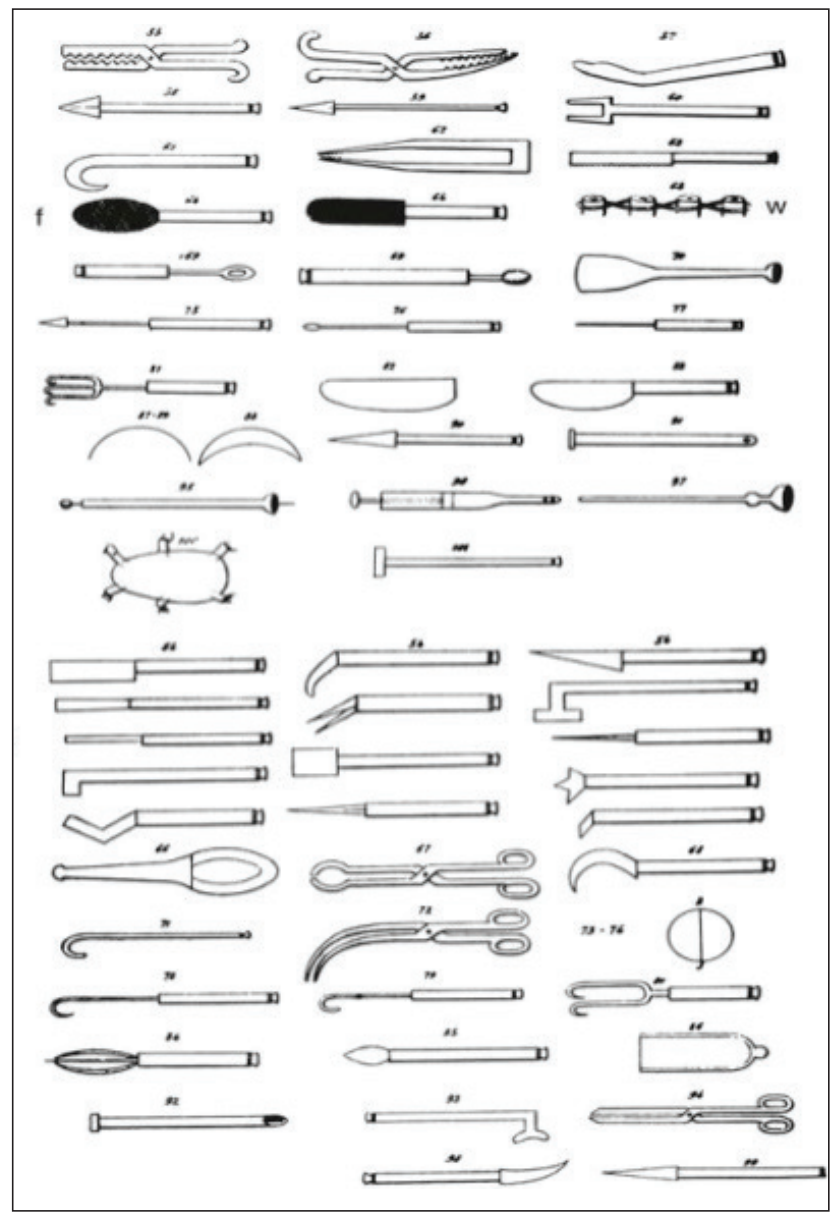

1 pav. Albukasio taikyti ịrankiai: f - dildès, sc - pjautuvèliai, w vielutè dantų tvirtinimui, taip pat žirklès ir peiliukai [1].
Daugumą procedūrų burnos ertmèje viduramžiais atlikdavo barzdaskučiai - chirurgai, kurie galèdavo ne tik nuskusti barzdą ar apkirpti plaukus. Dažnai žmonès ị šio amato atstovus kreipdavosi dèl dantų rovimo, kadangi barzdaskučiai - chirurgai savo cechuose turẻdavo ịvairių šiai procedūrai tinkamų instrumentų, buvo pratę atlikti ịvairias nedideles chirurgines intervencijas [10].

Renesansas. Renesanso laikotarpiu atgimè požiūris ị meną, literatūrą, taip pat ir mediciną. XV a. Albukasio darbus tęsè ir plètė turkas Serefedinas Sabunkuoglu (Serefeddin Sabuncuoglu) (3 pav.), kuris iliustravo patinusiu bei hipertrofavusių dantenų bei liežuvio pasaitèlio pašalinimo operaciją. Taip pat jis nurodè, jog patinusioms dantenoms, klibantiems dantims bei pūliniams pirmiausia turètų būti taikomas gydymas vaistiniais preparatais. Ir tik tuomet, jei šis gydymas nepadeda, reikètų atlikti chirurginę intervenciją, kuomet ikkaitintas specialus instrumentas yra ịvedamas ị kanulę ir dantenų audinys uždeginamas. Jei procedūra sèkminga, jaučiama šiluma gretimuose audiniuose [1].

XVI a. Bartolomejjus Eustakijus (Bartolomeo Eustachi) paraše traktatą apie dantis, sudarytą iš 30 skyrių, Jame buvo išsamiai aprašyti periodonto audiniai, jų ligos ir gydymas. Periodontito gydymui Eustakijus rekomendavo pašalinti kietąsias apnašas ir uždegiminį išvešèjusị audinį, t.y. atlikti granuliacinio audinio kiuretažą, kad galètų prisitvirtinti dantenos ir liktų vietos sveikiems periodonto audiniams $[1,2]$.

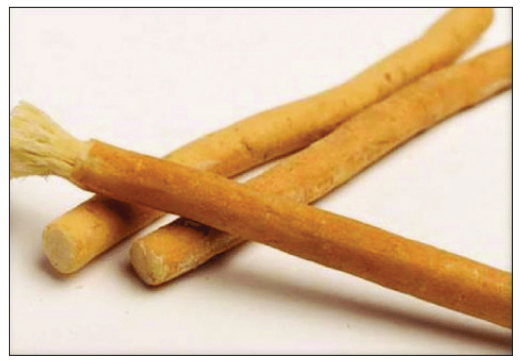

2 pav. Misvaka [9].

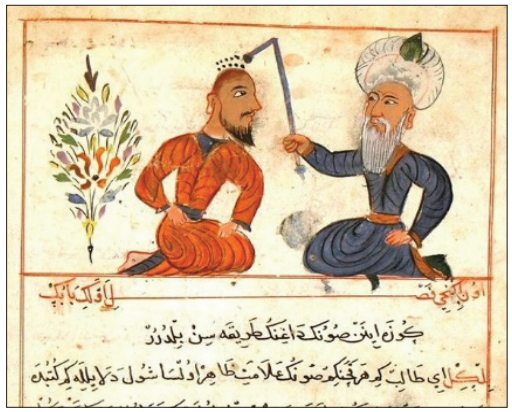

3 pav. Serefedinas Sabunkuoglu (13851468 m.) [11]. 
XVIII a. modernioji odontologija labiausiai vystèsi Europoje, ypač Anglijoje ir Prancūzijoje. Šiame amžiuje publikuoti traktatai, pristatytos mokslinès paskaitos, pirmieji chirurgai buvo specialiai mokyti odontologijos, atmestos nepagrisstos gydymo priemonès, o daugybè naudingų ir veiksmingų išradimų - užpatentuota [2].

Prancūzas Ambruazas Parè (Amroise Pare, 1509-1590 m.) buvo vienas ryškiausių Renesanso epochos chirurgų. Baigęs barzdaskučio - chirurgo mokslus, jis taikè ne tik dantų rovimą, bet ir gydomąsias burnos ertmès procedūras [12]. Savo rašytiniuose darbuose pažymėjo, jog svarbu dantų rovimą atlikti tinkamai, vengti komplikacijų, rauti tik tuos dantis, kuriuos reikia [13]. Taip pat jis taikè hipertrofavusiu dantenų gingivektomiją, suprato, kad kietosios dantų apnašos turi žalingos įtakos sveikam periodontui, tad naudodamas ivvairius pjautuvèlius jas šalino [1,2].

Svarbų vaidmeni periodontologijos istorijoje suvaidino ir Antonijus Levenhukas (Antonvan Leeuwenhoek, 1632 -1723 m.). Mikroskopu tyrinėdamas savo paties burnos ertmès audinių mėgini, pirmasis aprašè burnos ertmès mikroflorą, savo piešiniuose gana aiškiai iliustravo spirochetas bei bacilas (4 pav.) $[2,6]$.

Pjeras Fošaras (Pierre Fauchard, 1678-1761 m.), prancūzu chirurgas, laikomas šiuolaikinès odontologijos tévu. Jo dèka paprasta dantų priežiūros gydytojo praktika išaugo ị atskirą specialybę, laikoma rimta ir atsakinga profesija. Jo knyga „Chirurgas - dantistas" apèmè visas dantų priežiūros sritis, įtraukiant ir atkuriamają odontologiją, protezavimą, burnos chirurgiją, periodontologiją ir ortodontiją. Jis detaliai aprašè savo išrastus periodontologinius instrumentus (5 pav.) bei jų taikymą šalinant akmenis nuo

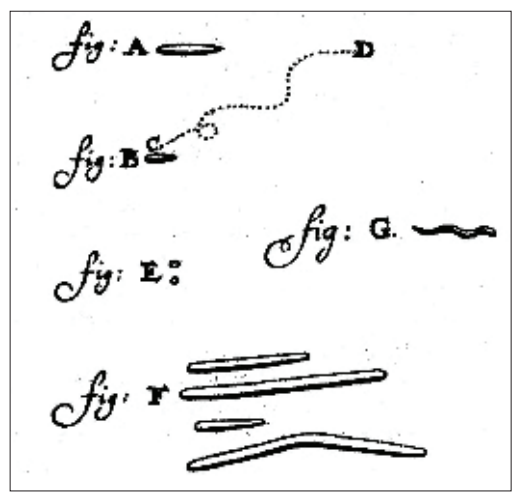

4 pav. Antonijaus Levenhuko bakterijų iliustracija, $1684 \mathrm{~m}$. [14]. dantų paviršių, taip pat nemažai dantenų stiprinimo ir gydymo priemonių [1]. Šis chirurgas pasiūlè klibančių dantų sutvirtinimą auksine vielute. Nors dauguma jo taikytų ir aprašytų gydymo būdų bei priemonių buvo atrastos dar seniau, jis atliko dideli darbą viską išsamiai aprašydamas. P. Fošaras pirmasis pradejo vartoti asmens higienos sąvoką. Savo knygos dèka šis žmogus pakeitè odontologijos praktiką, ikvèpè ir išugdè daugybę naujų odontologų kartų [1,2].

Džonas Hanteris (John Hunter, 1728-1793 m.) - britų chirurgas, parašè keletą reikšmingų traktatų apie dantų gydymą. Savo knygose jis pateikè labai aiškias dantų anatomijos ir juos supančių struktūrų iliustracijas ir apibūdino periodonto ligų ypatybes, atskyrè periodonto ligas nuo skorbuto požymių dantenose. Dž. Hanteris suprato, jog dantenų ligos gali sukelti dantų netekimą, taip pat aprašè kaulo netekimą ir dantenų kišenès susiformavimą, dantų padèties kitimus dèl šalia esančių dantų netekimo. Bendradarbiaudamas su Londone gyvenusiu stomatologu Džeimsu Spensiu (James Spence), jis iškèlè idejją apie vieno asmens dantų persodinimą kitam $[1,16]$.

XIX amžius apibūdinamas kaip pažangos, mokslo ir švietimo laikotarpis. Antroje XIX a. pusejje buvo atlikta reikšmingų atradimų, turejjusių įtakos ne tik moderniosios medicinos, bet ir odontologijos vystymuisi. Iki $1800 \mathrm{~m}$.

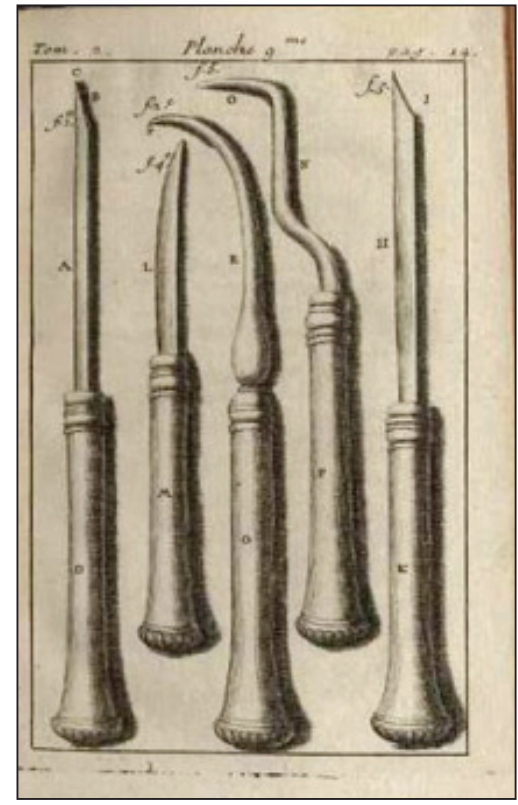

5 pav. Penkių rūšių instrumentai, kuriuos Pjeras Fošaras taikè akmenų šalinimui nuo dantų paviršių. Iš kairès: 1. Kaltas; 2. Išgaubtieji ašmenys; 3. „Papūgos snapas"; 4. Z formos kablys; 5. Raižiklis [15]. dantų specialistų, praktikuojančių vien tik burnos ir dantų priežiūrą bei gydymą, buvo nedaug, o iki XIX a. vidurio šios srities gydytojų skaičius ženkliai išaugo, tačiau nebuvo teisinio ar profesinio pobūdžio kontrolès, kuri padètų išvengti piktnaudžiavimo bei kompetencijos trūkumo $[1,2]$.

Šiuo laikotarpiu Levi S. Parmli (Levi Spear Parmly) pirmą kartą tarpdančių valymui pritaikè dantų siūlą [2,17]. $1779 \mathrm{~m}$. Hampris Deivis (Humphry Davy) paskelbia apie natrio oksido anestezines savybes ir pavadina šią medžiagą ,juoko dujomis“, o $1842 \mathrm{~m}$. Mortonas (Morton) pradeda anestezijai taikyti eterį. Danties rovimui pirmą kartą anesteziją pritaikè daktaras Velsas (Wells). Po kelerių metų vietinei anestezijai pradètas taikyti kokainas [18]. Kitą svarbų žingsnį žengè mikrobiologas ir vienas iš imunologijos pradininkų Luisas Pasteras (Louis Pasteur), atradęs fermentacijos ir daugelio žmogaus ligų šaltini, o Džozefas Listeris (Joseph Lister) pritaikè šį atradimą ir pradejjo naują - antiseptikos ir aseptikos - erą [1,7]. Dar vienas svarbus atradimas, pakeitęs iki tol egzistavusią odontologijos 
ir periodontologijos praktiką, buvo $1895 \mathrm{~m}$. Vilhelmo Rentgeno (Wilhelm Conrad Röntgen) išrastas rentgenografas [7].

Baltimorès odontologas Leonardas Kekeris (Leonard Koecker, 1785-1850 m.), remdamasis dantų chirurgijos principais, akcentavo, jog svarbu kruopščiai pašalinti dantų akmenis, taip pat skatino skirti dèmesio asmeninei burnos higienai kiekvieną dieną: ryte ir vakare po valgio, naudojant specialius miltelius ir dantų šepetèli, atsargiai turi būti nuvalomi dantų paviršiai. Kekeris pritarè infekcijos židinio teorijai ir rekomendavo pašalinti visus stipriai pažeistus dantis ir jų šaknis [1].

Pirmasis gydytojas, apribojęs savo praktiką periodontologijos srityje ir laikomas pirmuoju šios srities specialistu, yra Džonas Rigsas (John M. Riggs, 1811-1885 m.). Jis daugiausia savo dèmesio skyre periodonto ligoms, o jo praktikos laikotarpiu periodontitas buvo žinomas kaip „Rigso liga“. Šis specialistas savo moksliniuose raštuose išsake tvirtą požiūrị ị konservatyviają periodontologinių ligų terapiją. Taip pat jis pirmasis pavartojo burnos ligų profilaktikos sąvoką, kreipè dèmesị i burnos higieną, tačiau pasisakè prieš kai kurias chirurgines burnos procedūras. Rigsas sukūrẻ šešių rankinių instrumentų rinkinị, tinkamą šalinti kietụjų dantų apnašas $[1,2]$.

Pirmasis gydytojas, atpažinęs periodontitą sukeliančias bakterijas, buvo vokietis Adolfas Vicelis (Witzel, 1847-1906 m.). Pirmasis tikras burnos mikrobiologas buvo V. D. Mileris (Willoughby D. Miller, 1853-1907m.) [2]. Viename iš savo veikalų „Žmogaus burnos mikroorganizmai“ jis aprašè periodonto ligų savybes, ligas sukeliančių bakterijų kilmę ir šias ligas skatinančius veiksnius. Jis buvo įsitikinęs, jog šių ligų atsiradimą lemia burnos mikrofloroje esančios kelių rūšių bakterijos ir kad periodonto ligos gali būti ir kitų ligų priežastis. Mileris dantų apnašų svarbos patologiniame procese nepastebejjo, tačiau tai suprato Leonas Viljamsas (Leon J. Williams, 1852-1932 m.), kuris dantų apnašas apibūdino kaip bakterijų nuosèdas ant emalio paviršiaus $[1,2]$.

$\mathrm{XX}$ a. išvystyti histopatologiniai pagrindai, nuo kuriu prasidejo moderniosios periodontologijos era [5]. Bernardas Gotlibas (Bernhard Gottlieb) 1920 m. paskelbè savo mokslinius tyrimus, kuriuose aprašè dantenu epitelio ir danties jungtis, cementą, aktyvų ir pasyvų danties ėduonị. Gydytojas Oskaras Veskis (Oskar Weski) konkretizavo periodonto sandarą: danties cementą, dantenas, periodonto raištị ir alveolès kaulą [1].

Antrojoje XIX a. pusèje ịkurta Amerikos periodontologijos akademija periodiškai leido „Klinikinès periodontologijos“ žurnalą su naujausiais šios srities atradimais. Šiuo laikotarpiu dauguma JAV odontologijos mokyklų periodontologiją išskyrè kaip atskirą odontologijos sritį. Tobulèjant ir vystantis periodontologijos mokslui, tobulèjo ir keitèsi instrumentai. Todèl šiame straipsnyje norime panagrinèti vieną iš specifinių, svarbiausių, reikalingiausių diagnostinių instrumentų periodontologijoje - periodontologini zondą ir trumpai aptarti jo vystymosi istoriją.

Pirmos kartos periodontologiniai zondai. Periodontologiniai zondai yra graduoti instrumentai, skirti diagnozuoti dantenų kišenes ir išmatuoti jų gylị. Be to, šie zondai gali būti naudojami furkacijų identifikavimui ir matavimui, kraujavimo tendencijos nustatymui, akmenų lokalizavimui, dantenų recesijos matavimui, intraoralinių žaizdų dydžio nustatymui [19]. Periodontologiniai zondai gerokai ištobulèjo nuo vienapusio rankinio pirmosios kartos instrumento iki sudetingu kompiuterizuotu prietaisų. Pirmaji periodontologini zondą apraše Džonas Rigsas (John M. Riggs), o zondo pritaikymą praktikoje pirmą kartą apraše F. Simotonas (F. V. Simoton). Jis rekomendavo naudoti plokščius $1 \mathrm{~mm}$ skersmens ir 10 mm ilgio zondus[20,21].

H. Boksas (H.K. Box, 1928 m.) mokslo darbe „Periodontologinès kišenès gydymas“ iliustravo šešių periodontologinių zondų rinkinị, o vèliau jo darbą tęsè ir šį rinkinị patobulino bei aprašė V. Krosas (W.G. Cross, 1966 m.). Trijų tipų zondai buvo gaminami iš minkšto prabuoto sidabro ir buvo tinkami matuoti kišenès gyli ịvairiuose dantenu vagelès taškuose. Darbinè zondo dalis buvo sužymèta nuo $1 \mathrm{~mm}$ iki $6 \mathrm{~mm}$, o skirtingoms ištyrimo pusèms buvo naudojami atskiri instrumentai [20].

Remiantis tarp 1915 m. ir 1958 m. atliktais tyrimais buvo skatinama periodontologinį zondą naudoti dantenų audinių pažeidimo lygiui nustatyti. Šiuo laikotarpiu pats populiariausias dantenų kišenių tyrimui taikytas apvalią darbinę dali turintis kūgio formos zondas, $1936 \mathrm{~m}$. ištobulintas periodontologo Viljamso (C.H.M. Williams) [22].

Europoje periodontologiniai zondai pirmą kartą pritaikyti 1920 m. 1934 m. vokietis Strukmanas (Struckmann) aprašè šešių zondų, pagamintų iš nerūdijančio plieno, rinkinị. Zondų ilgiai buvo nuo 3 iki $8 \mathrm{~mm}$ ir prie periodonto kišenès galëjo būti pritaikomi švelniai paspaudžiant pirštu. 1946 m. E. Fišas (E.W. Fish) pristate savo patobulintą zondą. Jis buvo ịsitikinęs, jog nẻra didelio poreikio keisti iki šiol ịprastai naudotu zondu ilgi, bet buvo isitikinęs, jog zondo galas turi būti apvalus, kad sumažètų zondavimo metu paciento patiriamas diskomfortas [20].

Panašiu laikotarpiu Tokijo medicinos ir odontologijos universitete Kimura aprašè du darbinius galus turintị periodontologinį zondą, kurio $15 \mathrm{~mm}$ ilgo galas buvo sužymètas devyniomis skirtingų spalvų juostelėmis, kiekvienos plotis buvo $0,7 \mathrm{~mm}$. Tarp juostelių buvo $0,3 \mathrm{~mm}$ pločio tarpeliai, kurių dèka buvo lengva ịvertinti zondavimo gyli, taip pat jie buvo gerai matomi rentgeno spinduliais [20].

1967 m. Šmitas (Schmidt) pristate plastikinị periodonto 
zondą. Jis teigè, jog kiti tuo laikotarpiu taikyti zondai buvo per stori ir per kieti, todèl jo sukurtas metalinis zondas su plastmasine keičiama darbine dalimi buvo lengviau pritaikomas dantenų kišenejje ir prie danties šaknies paviršiaus. Darbinio galo ilgis buvo $9 \mathrm{~mm}$, sužymètas kas 3, 6 ir $9 \mathrm{~mm}$, o pats galas buvo vos $0,2 \mathrm{~mm}$ storio [20].

1978 m. Pasaulinè sveikatos organizacija (PSO) specialu periodontologini zondą, kurio gale buvo $0,5 \mathrm{~mm}$ skersmens rutuliukas, rekomendavo taikyti periodonto gydymo reikmiu indeksui nustatyti. Apvalus galas buvo skirtas geriau pajusti po dantenomis esančias kietąsias apnašas[20].

Pirmosios kartos periodontontologiniai zondai yra lengvai prieinami, nebrangūs, pasižymi geru taktiliniu jautrumu ir bendrosios praktikos gydytojų odontologų ir gydytojų periodontologų naudojami dažniausiai. Tačiau dèl trūkumų - negalima pamatuoti ir kontroliuoti zondavimo jègos bei reikia asistento duomenims registruoti - vélesniais metais šios kartos zondai buvo tobulinami [19].

Antros kartos zondai. Ilgą laiką periodontologiniai zondai taikyti periodonto būklei įvertinti. Tačiau Mulemanas (Muhlemann) ir Mazoras (Mazor) 1958 m. suprato dantenų kraujavimo švelnaus zondavimo metu ryši su gingivitu, tad nuo to laiko pradèta kreipti dèmesị ị kuo mažesnị spaudimo jègos panaudojimą zonduojant [20]. Antrosios kartos zondai yra jautrūs spaudimui. Jie užpilde kai kuriuos pirmosios kartos zondų trūkumus, tačiau jiems vis dar trūko taktilinio jautrumo, o duomenis reikejjo registruoti rankiniu būdu [19,23]. Vaerhaugas (Waerhaug) $1952 \mathrm{~m}$. rekomendavo zondavimui taikyti švelnią rankos jègą, kuri neturètų viršyti $0,2 \mathrm{~N} /$ $\mathrm{mm}^{2}[19,21]$.

Pirmasis spaudimui jautrus periodontologinis zondas buvo išrastas $1971 \mathrm{~m}$. Gabatulerio (Gabathuler) ir Haselio (Hassell). Jis buvo sudarytas iš standartinio ZIS periodonto zondo bei pjezoelektrinio spaudimo jutiklio [20]. $1978 \mathrm{~m}$. Veldenas (Van der Velden) ir Vrisas (de Vries) pristate zondą, kurio spaudimo jèga buvo reguliuojama. Darbinis šio zondo galas buvo sudarytas iš $1 \mathrm{~mm}$ skersmens metalinio cilindro, išlenkto $130^{\circ} \mathrm{kampu}$. Šiuo zondu zondavimo jèga keitèsi nuo $0,32 \mathrm{~N} / \mathrm{mm}^{2}$ iki $4,81 \mathrm{~N} / \mathrm{mm}^{2}$. Polsonas (Polson) ir kt. $1980 \mathrm{~m}$. pristate elektrinị spaudimui jautrų periodontologini zondą, kurio išvaizda priminè rašikli su zondavimui skirtu galu. Zondavimo jègą buvo galimą reguliuoti elektroniniu reguliavimo prietaisu, parenkant spaudimo jègą nuo 0,05 $\mathrm{N}$ iki $1 \mathrm{~N}$ [20].

Trečiosios kartos zondai. Nustatant kišenių gylį ankstesniaisiais zondais, buvo neišvengiama paklaidų, kurios atsirasdavo ịvertinant bei užrašant zondavimo duomenis. Šių žmogiškų klaidų buvo galima išvengti pasitelkiant kompiuterius $[19,20]$. Programine įranga integruojama ị naudojamus kompiuterius, siekiant kompiuterizuoti periodonto vertinimą
[22]. Pirmasis kontroliuojamą spaudimo jègą turintis zondas, galintis automatiškai ịvertinti epitelio jungties prisitvirtinimo lygi, o gautus duomenis perkelti i kompiuterị, buvo pristatytas Džefkoto (Jeffcoat) 1986 m. [20]. Šis zondas turi apvalų galiuką, kuris slenka palei šaknies paviršių kontroliuojamu greičiu ir spaudimu. Staigus zondo judejjimo pagreičio pasikeitimas rodo, kad buvo pasiekta cemento - emalio jungtis (CEJ). Zondui sustojus, nustatomas kišenès dugnas. Pagrindinis privalumas - CEJ nustatymas (geresnis atskaitos taškas nei dantenų kraštas). Pagrindinis trūkumas - zondas gali šaknies šiurkštumą ir nelygumus palaikyti CEJ [19].

Birekas (Birek) ir Makulokas (McCulloch) 1987 m. išvystė Toronto automatizuotą periodontologini zondą, kuris gebejo kontroliuoti zondavimo jègą, automatiškai surinkti duomenis, juos saugoti bei atkurti zondavimo kampą [20].

Prie trečiosios kartos zondų priskiriami Florida zondai. Pirmasis Florida zondas išleistas 1987 m. Gibso (Gibbs). Tai viena iš labiausiai automatizuotų zondavimo sistemų, kuri efektyviai atlieka jungties epitelio prisitvirtinimo analizę. Taip pat šis zondas labai plonas $(0,2 \mathrm{~mm})$ ir lengvas (15 g) [22]. Zondas sužymètas pagal Williams pasiūlytą sistemą, kišenių gylis įvertinamas elektroniniu būdu ir automatiškai persiunčiamas ị kompiuterị [24]. Šis zondas gali ịvertinti ne tik kišenių gylį, bet ir dantenų atsitraukimą, kraujavimą, pūlinius, furkacijas, dantų paslankumą bei apnašas. Florida zondas vertina 2 mm tikslumu [19,24]. Kompiuteryje sudaroma lentelé, kurioje pavaizduojami matavimų duomenys (sistema sužymi juodas rodykles, kur pokyčiai yra 1-2 mm ir raudonas, kur $>2 \mathrm{~mm}$ ). Šią lentelę galima naudoti kaip vizualinę paciento mokymo priemonę [19].

1992 m. pristatytas Interprobe zondas, turintis lanksčią darbinę dalị. Skirtingai nei nerūdijančio plieno zondai, kurie skausmingai atstumia dantenas nuo danties, Interprobe švelniai ịslysta ị dantenų vagelę ir linksta pagal danties formą [19].

Šios kartos zondai yra labai tikslūs, bet pasižymi mažesniu taktiliniu jautrumu ir labai brangūs, todèl aukšta kaina yra priežastis, dèl kurios šie zondai naudojami gana retai, daugiausia moksliniams tyrimams $[19,23]$.

Ketvirtosios ir penktosios kartų zondai. Ketvirtosios kartos periodontologinių zondų veikimo principas yra paremtas 3D technologija ir nuosekliu periodonto būklès ịvertinimu. Jų tikslas yra detaliai ir nuosekliai ịvertinti dantenų vagelès ir kišenès dugną, pagal linijinių matavimų seriją sukuriant 3D vaizdą. Šios kartos zondai pasižymi invazyvumu ir vis dar yra tobulinami. Penktosios kartos periodontologiniu zondu periodonto būklè iqvertinama be invazijos. Jis veikia echografijos principu, kai tiriama ultragarsu, o gauti ištyrimo rezultatai pavaizduojami grafiškai. Taip išvengiama jungties epitelio pažeidimų, o gauti duomenys yra labai tikslūs. Šie zondai vis dar tobulinami $[19,21,23,24]$. Penktosios kartos 
periodontologinių zondų pavyzdys yra Ultrasonographic (US) zondas, kuris naudoja ultragarsą viršutinès periodonto raiščio ribos ir jos variacijų nustatymui ir atvaizdavimui. Siauras ultragarso energijos pluoštas projektuojamas tarp danties ir kaulo tokiu pačiu kampu kaip ir standartinis zondas ir vedamas išilgai dantenų vagelès. Gaunamas grafinis vaizdas bei duomenys apie dantenų audinių būklę [19].

Kiti periodontologiniai zondai. Be ịprastinių periodontologinių zondų, skirtų dantenų kišenių gylio matavimui, buvo kuriami ir tobulinami zondai, skirti periodonto audinių uždegimui nustatyti. Sukurtas zondas, matuojantis sulfidų koncentracijas, kaip gramneigiamų bakterijų aktyvumo indikatorių, ir taip nustatantis periodonto ligą (The Diamond Probe ${ }^{\circledR} /$ Perio $2000 \AA$ System). Sistemą sudaro vienkartinè zondo darbinè dalis su mikrosensoriais, prijungtais prie pagrindinès sistemos. Zondas gali nustatyti periodonto uždegimą ankstyvoje stadijoje, rasti aktyvią zoną, kuriai reikalingas gydymas bei nustatyti taikyto periodontologinio gydymo efektyvumą. Šio tipo zondų trūkumai yra nekontroliuojamas zondavimo spaudimas bei negebejimas nustatyti ligą sukèlusių bakterijų, kurios neišskiria sieros junginių $[19,25,26]$. Ankstyviems uždegiminiams pokyčiams diagnozuoti taip pat gali būti naudojamas temperatūrinis zondas (The Periotemp ${ }^{\circledR}$ Probe), kuris yra jautrus $0,1^{\circ} \mathrm{C}$ temperatūros pokyčiams [19]. Podanteninè temperatūra priklauso nuo danties lokalizacijos burnoje, periodonto audinių kišenès gylio, prisitvirtinimo lygio, uždegimo laipsnio. Atliktų tyrimų metu ịrodyta, kad podanteninè temperatūra yra aukštesnè uždegimo paveiktose srityse, lyginant su sveikomis dantenomis. Taip pat nustatytas temperatūrų skirtumas tarp priekinių ir galinių dantų lankų segmentų. Priekinių dantų podantenineje srityje temperatūra paprastai būna keliais ${ }^{\circ} \mathrm{C}$ žemesnè nei krūminių dantų srityje [27]. Padidejjusi podanteninè temperatūra rodo padidejjusią dantenų prisitvirtinimo lygio praradimo riziką ateityje [28]. Tačiau duomenys gali būti netikslūs dèl oro srovès kvejpuojant [19].

\section{Išvados}

Per keletą tūkstantmečių žmonès nuolat ieškojo būdų periodonto ligoms išgydyti ar nuslopinti jų sukeliamiems simptomams. Bègant laikui buvo suprasta ir burnos higienos svarba, siekiant išvengti periodonto ligų. Apie įvairiais istorijos laikotarpiais taikytas priemones sužinoma iš išlikusių istorinių šaltinių, kurių dèka periodontologijos sritis nuolat tobulèja. Nuolatinis geresnių ir veiksmingesnių priemonių ieškojimas bei tobulinimas didina periodonto ligu gydymo sèkmingumą bei padeda užkirsti kelią šioms ligoms.

\section{Literatūra}

1. Newman M, Takei H, Klokkevold P, Carranza F. Carranza's
Clinical Periodontology. 12th ed. English: Saunders 2015; 1-8.

2. Brkić Z, Pavlić V. Periodontology-the historical outline from ancient times until the 20th century istorijski razvoj parodontologije. Vojnosanit Pregl 2017;74(2): 193-199.

https://doi.org/10.2298/VSP150612169B

3. Shinde M. Ancient history of periodontics. 2015 [viewed 2019 Jan 28]. https://www.slideshare.net/mehulshinde2/ancienthistory-of-periodontics

4. Boloor VA, Hosadurga R, Rao A, Jenifer H, Pratap S. Unconventional dentistry in India - an insight into the traditional methods. J Tradit Complement Med. 2014;4(3):153-8.

https://doi.org/10.4103/2225-4110.130951

5. Shklar G, Carranza FA. The historical background of periodontology. Carranza's Clinical Periodontology 2012; 2-9. https://doi.org/10.1016/B978-1-4377-0416-7.00001-9

6. Munjal S, Munjal S. Evolution of periodontics: an insight into the past. Int J Basic Appl Med Sci 2014; 21-28.

7. Gurudath G, Vijayakumar K V, Arun R. Oral hygiene practices: ancient historical review. Oral Hyg Pract Anc Hist Rev J Orofac Res 2012; 2:225-7.

https://doi.org/10.5005/jp-journals-10026-1047

8. Med AS. Arab and Muslim physicians and scholars. Ann Saudi Med 2007 [viewed 2019 Jan 28].

9. Meswak chewing stick, n.d. photograph [viewed 2019 Jan 28]. https://www.researchgate.net/figure/Meswak-chewingstick_fig2_323388369

10. Titor J. History of dentistry: from barber-surgeons to dentists. History Daily, 2016 [viewed 2019 Jan 27].

11. Sabuncuoglu O, Ayduz S. The 15th Century Turkish physician serefeddin Sabuncuoglu Author of Cerrahiyetu 'l-Haniyye [viewed 2019 Jan 29]. http://muslimheritage.com/article/15thcentury-turkish-physician-serefeddin-sabuncuoglu-authorcerrahiyetu- $\% \mathrm{E} 2 \% 80 \% 981$-haniyye

12. Encyclopaedia Britannica. Ambroise Paré. [viewed 2019 Jan 27]. https://www.britannica.com/biography/Ambroise-Pare

13. Parry C. Renaissance dentistry. Heritage Blog [viewed 2019 Jan 27]. https://heritageblog.rcpsg.ac.uk/2013/11/11/renaissance-dentistry/

14. Drawings of animalcules form Leeuwenhoek's letter, 17th September 1683 to the Royal Society in London, n.d. photograph [viewed 2019 Jan 29]. https://www.sciencephoto.com/ media/230812/view/drawings-of-animalcules-form-leeuwenhoek-s-letter

15. Fauchard P. Le chirurgien dentiste, ou Traité des dents. Ou l'on enseigne les moyens de les entretenir propres \& saines, de les embellir, d'en réparer la perte $\&$ de remedier à leurs maladies, à celles des Gencives \& aux accidens qui peuvent survenir aux autres parties voisines des dents. Avec des Observations \& des reflexions sur plusieurs cas singuliers. Jean Mariette. 1728. https://gallica.bnf.fr/ark:/12148/bpt6k106170j.image

16. Kapp KA, Talboy GE, Kapp K. John Hunter, the father of scientific surgery 2017. 
17. Prichard D. A brief history of dental floss. Spear Education. 2013. https://www.speareducation.com/spearreview/2013/01/a-brief-history-of-dental-floss

18. Prichard D. A brief history of dental anesthesia. Spear Education 2013. https://www.speareducation.com/spearreview/2013/08/a-brief-history-of-dental-anesthesia

19. Ramachandra SS, Mehta DS, Sandesh N, Baliga V, Amarnath J. Periodontal probing systems: a review of available equipment. Compend Contin Educ Dent 2011;32(2):71-7 [cited 2019 April 10].

20. Hefti AF. Periodontal probing. Crit Rev Oral Biol Med 1997; 8:336-56. https://doi.org/10.1177/10454411970080030601

21. Dr.Thakur M. Periodontal probes. 2016 [viewed 2019 Jan 28]. https://www.slideshare.net/malvika014/periodontalprobes-64860621

22. Dr Kazim J. Periodontal probing and techniques. 2014 [viewed 2019 Jan 28]. https://www.slideshare.net/DrJohnnKazimm/ periodontal-probing-and-techniques

23. Martu A, Popa C, Luchian IA, Martu I, Oanta C, Martu S. Evaluation of the efficiency of 2 types of periodontal probing. Balk J Dent Med 2015; 19:163-166. https://doi.org/10.1515/bjdm-2015-0054

24. Nitin Gupta M, Rath CS, Parul Lohra M. Comparative evaluation of accuracy of periodontal probing depth and attachment levels using a Florida probe versus traditional probes. Med J Armed Forces India 2015; 71(4): 352-358.

https://doi.org/10.1016/j.mjafi.2012.02.018

25. Pavolotskaya A, McCombs G, Darby M, Marinak K, Dayanand NN.Sulcular sulfide monitoring: an indicator of early dental plaque-induced gingival disease. J Dent Hyg 2006; 80(1):11.

26. Torresyap G, Haffajee AD, Uzel NG, Socransky SSJ. Relationship between periodontal pocket sulfide levels and subgingival species.Clin Periodontol 2003; 30(11):1003-10.

https://doi.org/10.1034/j.1600-051X.2003.00377.x

27. Haffajee AD, Socransky SS and Goodson JM: Subgingival temperature (I). Relation to baseline clinical parameters. J Clin Periodontol 1992; 19: 401-408.

https://doi.org/10.1111/j.1600-051X.1992.tb00670.x

28. Haffajee AD, Socransky SS and Goodson JM: Subgingival temperature (II). Relation to future periodontal attachment loss. J Clin Periodontol 1992; 19: 409-416.

https://doi.org/10.1111/j.1600-051X.1992.tb00671.x

\section{THE DEVELOPMENT OF PERIODONTOLOGY THROUGHOUT THE HISTORY. CONTEMPORARY PERIODONTAL PROBES}

M.Ambrazaitytė, M.Kalinaitė, E.Jagelavičienė

Keywords: periodontology, historical background, periodontal probe.
Summary

People have suffered from periodontal diseases since the ancient times. Various signs of diseases of the oral cavity and teeth have been found while examining prehistorical human remains. Also, ways of treatment have been preserved in written sources of early civilizations. People have tried numerous remedies to treat the conditions: herbs, spells, prayers. However, effective methods of treatment have been discovered a while later. Modern treatment, which requires more complex instruments and is based on scientific knowledge, originated in the 18th century. Before the midle of the 19th century, periodontal diseases were treated by extracting teeth or roots of the teeth. Besides, a lot of measures were tried to reduce unpleasant symptoms. Before the development of periodontal indices in 1950, periodontal health had been evaluated very subjectively, by categorizing it to mild, moderate and severe. Futhermore, it was impossible to compare results of treatment and studies performed by several doctors as they were too subjective and intuitive. That is why prevalence of periodontal diseases varied from 8 to 98 percent. Now the modern tools of periodontal diagnosis are very sensitive, effective and much more objective.

The aim is to perform review of literature, to analyze the development of periodontology throughout the history and collect the data about contemporary periodontal probe generations.

Material and the methods. Medline, PubMed Central and Elsevier databases were used for data searching, the articles published in English were selected according to the keywords: periodontology, historical background, periodontal probe. Periodontal textbooks were analyzed of which 28 literature sources met the predefined criteria and were chosen.

Results. Data about the methods used to treat periodontal diseases throughout the historical periods, tools and medicines, historical sources, founders of treatment methods and the development stages of instruments has been collected.

Conclusion. Throughout the millenials people searched for methods how to treat periodontal diseases and relieve the symptoms. Historical sources show what tools and methods were used before, enabling the constant development of periodontology. The development of contemporary instruments and treatment protocols increase the higher success of periodontological treatment.

Correspondence to: egle.jagelaviciene1@gmail.com

Gauta 2019-06-04 